症 例

選択的脾動脈塞栓術（SAE）により脾機能六進症が改善され， 転移性肺癌に対して化学療法が可能となった 1 例

\begin{tabular}{|c|c|c|c|c|c|c|c|}
\hline 梅 & $\begin{array}{l}\text { 日本因林 } \\
\text { 原 松 }\end{array}$ & 臣 & 足 & $\begin{array}{l}\text { 科（主任：， } \\
\text { 立 幹 夫 }\end{array}$ & 鄭 & & \\
\hline 金 & 徳 & 栄 & 青 & 伸 弘 & 田 & 中 & 洋 \\
\hline 田 & 尻 & 孝 & $\begin{array}{l}\text { 山 } \\
\text { 局 }\end{array}$ & $\begin{array}{l}\text { 下 精 彦 } \\
\text { 放射線科 }\end{array}$ & 恩 & 田 & 昌 \\
\hline 細 & 井 盛 & - & $\begin{array}{l}\text { 本 } \\
\text { 同 }\end{array}$ & $\begin{array}{l}\text { 多 一 義 } \\
\text { 泌尿器科 }\end{array}$ & 隈 & 崎 & 達 \\
\hline
\end{tabular}

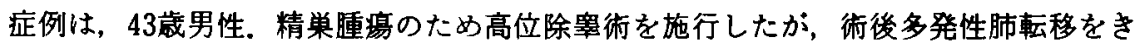
たした，化学療法を考虑するも，日本住血吸虫症による脾機能立進症のため，白血球数 $2,200 / \mathrm{mm}^{3}$, 血小板数 $6.4 \times 10^{4} / \mathrm{mm}^{3}$ と著明に低下していた。そこで, 脾機能克進症改善 の目的で, 選択的脾動脈塞栓訹 (Splenic artery embolization, SAE) を施行したとこ ろ, 白血球数と血小板数が著明に增加し，安全に化学療法を開始することができた。制 癌剂は, Etoposide, Cisplatin, Vinblastine, Bleomycin を使用し，投与後䄪 4 カ月で, 転移性肺癌の消失をみた。なお，制癌剤投与後一過性に白血球数の減少がみられたが， 休薬により回復した。一方血小板数は制癌剤投与の影響を受けなかった。 4 力月後の現 在でも，白血球数 $5,000 / \mathrm{mm}^{3}$ 前後，血小板数 $20 \times 10^{4} / \mathrm{mm}^{3}$ 前後を維持している.

本症例のごとく，脾機能六進症に悪性腫場が合併することは決して稀ではない，この 様な症例では，沉血球减少症が問題となり，化学療法が躊署されることが少なくない， SAEにより脾機能六進症が改善され，かつ安全に化学療法を行ならことができた症例を 経験したので，若干の文献的考察を加え SAEの有用性を報告する。

索引用語：選択的脾動脈塞栓術, 脾機能六進症, 化学療法

\section{I. 緒 言}

脾機能元進症を有する症例に，悪性腫湯が併存する ことは決して稀ではない，このよらな症例に対する化 学療法に打いては, 沉血球减少症のため, 制癌剂投与 が跨踳されることが少なくない，今回我々は，脾機能 亢進症を有し，精巣瘇湯手術後に転移性肺癌をきたし た症例に, 選択的脾動脈塞栓術 (Splenic artery embolization, 以下 SAE と略)を施行し，化学療法を安全に 行ならことができ，かつ転移性肺癌が消失した症例を 経験したので，若千の文献的考察を加吕報告する.

\section{II. 症例}

患者：43歳, 男性. 自営業.

主訴：右辠丸腫大。

家族歴：特記すべき事なし。
既往歴：18歳の時, 日本住血吸虫症の診断を受けて いる.

現病歴：昭和59年 6 月頃より右瞕丸の腫大に気つ き，徐々に增大するため, 同年 9 月当院必尿器科を受 診，入院となる．右鼻丸は， $3 \times 3 \mathrm{~cm}$ 大に腫大し，弾性 硬，表面平滑であった。，右精巣尰湯の診断で，同年 9 月11日右高位除鼻術を施行された。病理組織学的には 精上皮腫と胎児性癌の混合腫痬であった。術後程過良 好で退院したが，約 1 力月後两肺野に数 $\mathrm{mm} \sim \mathrm{lcm}$ の 多発する結節陰影を認め, 転移性肺癌の診断のる同 年10月29日再入院となる(写真 1)。入院後化学療法を 考虑したか，末梢血液検查所見で，白血球数と血小板 数が著明に低下しており，制癌剤投与が躊躇された。 血液疾患の存在はなく，日本住血吸虫症に続発した脾 
機能六進症によるものと診断し，同年11月20日脾機能 元進症改善の目的で, 外科転科となる。

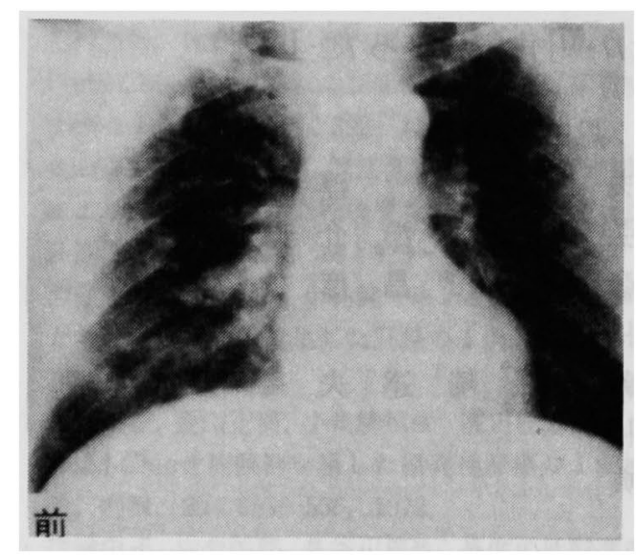

写真 1 入院時胸部レントゲン写索

\begin{tabular}{|c|c|c|c|}
\hline WBC & $2200 / \mathrm{mm}^{3}$ & & \\
\hline RBC & $425 \times 10^{4} / \mathrm{mm}^{3}$ & & \\
\hline $\mathrm{Hb}$ & $13.1 \mathrm{~g} / \mathrm{d} \ell$ & & \\
\hline $\mathrm{Ht}$ & $37.1 \%$ & & \\
\hline$P_{t}$ & $6.4 \times 10^{4} / \mathrm{m}^{3}$ & & \\
\hline GPT & $54 \mathrm{U} / \mathrm{\ell}$ & TP & $6.5 \mathrm{~g} / \mathrm{d} \ell$ \\
\hline GOT & $26 \mathrm{U} / \mathrm{s}$ & $C h-E$ & $6.35 \mathrm{KU} / \mathrm{e}$ \\
\hline Al-p & $76 \mathrm{U} / \mathrm{e}$ & HPT & $75 \%$ \\
\hline LDH & $195 \mathrm{U} / \mathrm{\ell}$ & AFP & $2.4 \mathrm{ng} / \mathrm{ml}$ \\
\hline$\gamma$-GTP & $47 \mathrm{U} / \mathrm{R}$ & CEA & $2.0 \mathrm{ng} / \mathrm{ml}$ \\
\hline TBil & $1.1 \mathrm{mg} / \mathrm{de}$ & $\mathrm{HBAg}$ & $(-1) \quad A b(-)$ \\
\hline
\end{tabular}

転科時現症：体格，栄盖中等度. 貧血, 黄疸なし。 局所再発の所見は認められなかった，表在リンバ節触 知せず。左季肋下に脾を 2 横指触知した。

転科時血液検查：表 1 に示すごとく，白血球数 $2,200 / \mathrm{mm}^{3}$ ，血小板数 $6.4 \times 10^{4} / \mathrm{mm}^{3}$ と著明に低下し ている以外異常を認めなかった。

経過：同年11月21日，SAEを施行した（写真2）。 SAEは, Seldinger 法にてカテーテルを脾動脈脾内枝 まで㨉入し，約 $2 \mathrm{~mm}$ 角の Gelfoam 細片を用いて行 なった，血管造影上䄪 $60 \%$ の部分塞栓とした。

$\mathrm{SAE}$ 後, 䄪 1 週目より白血球数及び血小板数の著明 な增加がえられ，3 週後白血球数 $5,000 / \mathrm{mm}^{3}$, 血小板 数 $20 \times 10^{4} / \mathrm{mm}^{3}$ となったところで，化学㞠法を開始し た(図 1)。制癌剂はEtoposide (VP-16)を120mg/day， 6 日間投与を 1 cycle として 2 cycle 投与し（図 1，(1) (2)), その後 Cisplatin (CDDP), Vinblastine (VLB), Bleomycin (BLM) の 3 者併用䖍法 (PVB 療法)を行 なった. 即ち, CDDP $30 \mathrm{mg} /$ day を 5 日間連続，VLB $20 \mathrm{mg} / \mathrm{day}$ を 1 日，BLM $30 \mathrm{mg} / \mathrm{day}$ を 1 日，以上を 1 cycle とし，2 cycle 投与した（图 1 ，(3)(4)）．制癌昘投 与中の血球数の推移をみると，白血球数は一過性に减 少したか，休薬により正常域に復した，一方，血小板 数は制癌剤投与の影響をほとんど受けず，4力月後の 現在でも， $20 \times 10 \% / \mathrm{mm}^{3}$ 以上の值を維持している.

SAE 後の合併症として, 約 1 週間の発熱をみたか， 対症的処置で軽快した。腹痛はほとんどみられなかっ た. 制癌剤投与を開始してから4 カ月後の胸部レント

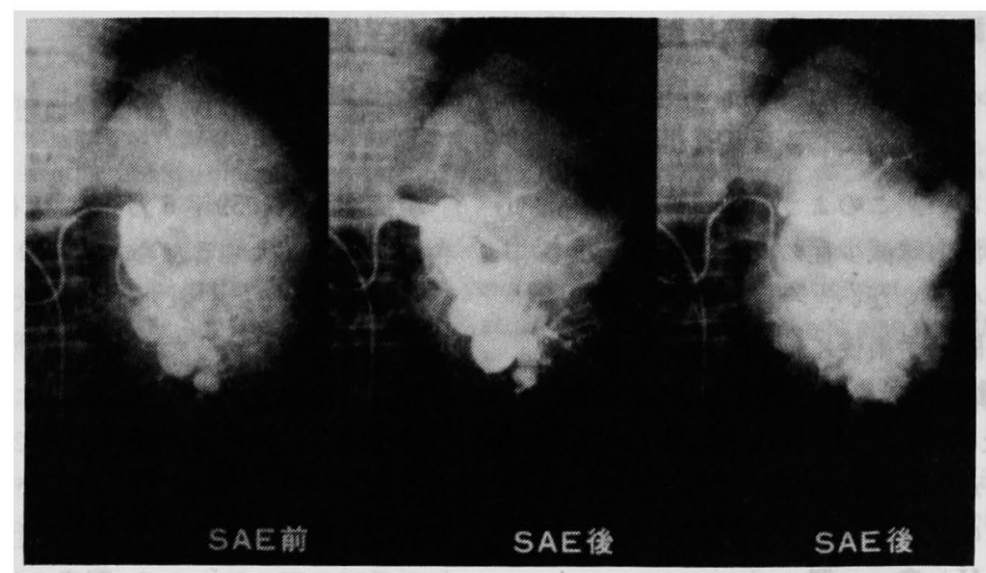

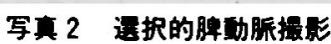

左：SAE 前の脾動脈相

中 : SAE 後の脾動脈相

右：SAE 後の脾毛細血管相 


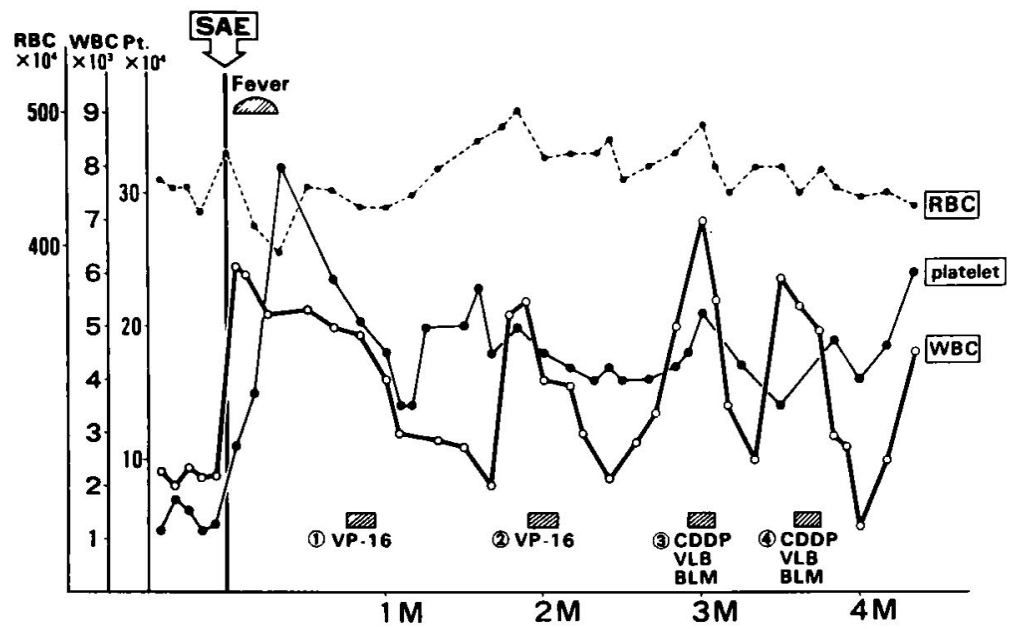

图 1 SAE 後の末梢血液所見

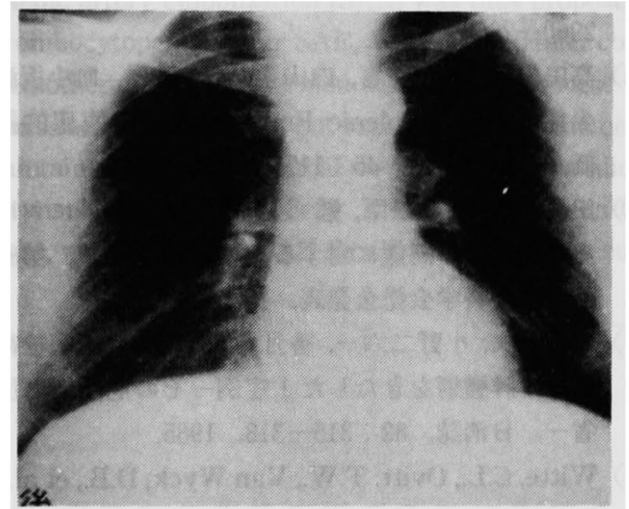

写乗 34 カ月後の䑦部レントゲン写真

ゲン写真では，肺転移巣は消失している（写真 3 ).

SAE 後の脾の変化をCTでみると, 1 週後に較ぺて 3 カ月後では，梗塞された脾実質が吸収，縮小してい る. 一方, 正常脾実質の増大は認められない(写真 4$)$.

\section{III. 考 察}

脾動脈塞拴術は，1973年 Maddison ${ }^{1)}$ により報告さ れ, 1979年 $\mathrm{Spigos}^{2}{ }^{2}$ が部分塞栓術を報告して以来, 本邦 でも数多〈実施されるようになってきている(3) . 脾 摘に比し，血小板数の增加と持続の程度は劣るむの の”, non-surgical splenectomyとしての有用性は確 立された感がある，ところで本症例のごとく，脾機能 亢進症に悪性腫瘍が合併することは少なくなく，特に 化学潦法を行なら場合は, 汎血球减少症が問題となっ てくる. 本来, 精巣腫瘍は, 化学療法あるいは放射線 療法に対して, 他の悪性腫瘍に比し感受性があり，手

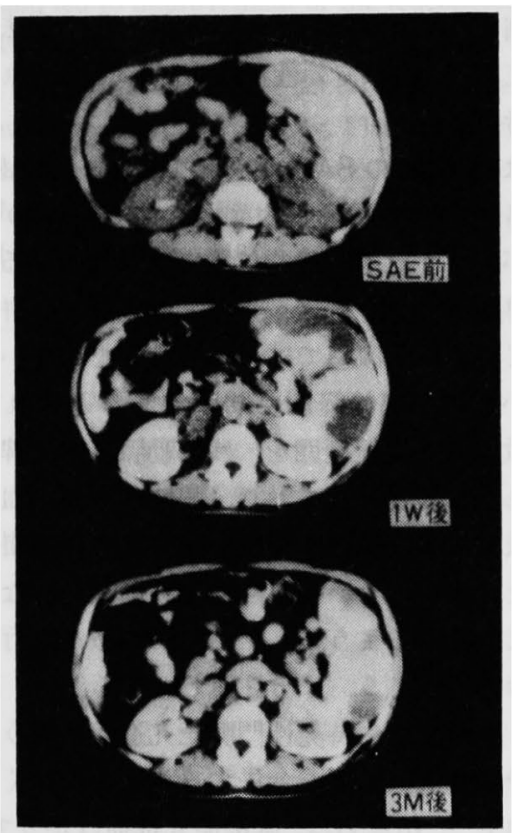

写真 4 SAE 後の CT 像

術及びこれらの治療法が可能であれば，転移巣をむ含 め治瘦を期待できるすのである. しかし本症例は日本 住血吸虫症により, 高度の脾機能元進症を呈しており, 転移巣に対しての化学㞠法を行ならには，まず脾機能 亢進症の治療が必要であった，そこで，脾摘をせずに $\mathrm{SAE}$ を施行したところ, 白血球数と血小板数の减少が 改善され，化学療法を安全に行ならことができた．経 過中制癌剤投与により，一過性に白血球数の減少を示 したが，休薬により再び増加した。また，血小板数は 
表 2 数室での脾機能え進症に対するSAE施行例

(S. 56. $11 \sim$ S. 60.4 )

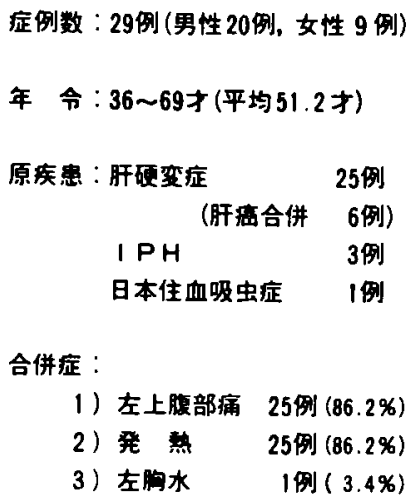

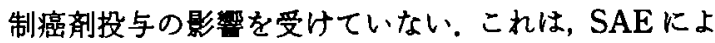
る脾機能立進症の改善が, 一過性のむのではなく, 長 期にわたって有効であることを示すものである，さら に本症例では転移巣の消失がみられ，化学療法の前処 置としてのSAEの有効性は，大いに評価されるべき ものと考える.

表 2 は，教室でのSAE 症例とその合併症である.諸 家の報告同様 ${ }^{3(-5)}$, 大多数の症例で発熱，腹痛がみられ ているか，いずれる対症的処置で軽快している. 文献

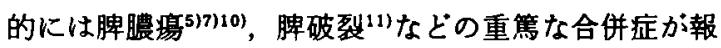
告されているが，教室では未だ経験していない，この 点については, 塞拴範囲が問題であるとされている

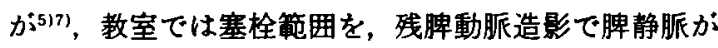
描出されらる程度としており，脾のらっ血，血流停滞 及び門脈系よりの逆行性感染を防ぐように心却けてい る。また，脾が大きい程 1 回の塞栓籁囲を少なくし， 段階的に塞栓するようにしており，急敫な血行動態の 変化をおこさぬよら，十分注意している。

一方, 肝硬変症や特発性門脈王六進症に伴亏脾機能 六進症では食道静脈瘤を合併することが少なくない， 教室の山下 ${ }^{12)}$, 田尻らは, 脾機能六進症ばかりでなく， 食道静脈瘤や肝機能, 全身状態の改善に対しても, SAEが有効であると報告している。

以上より, SAEは安全に施行でき, 脾機能進症に 対し有効であり，広く活用しらるものと考える。

$$
\text { IV. 結 語 }
$$

1）脾機能え進症及び転移性肺癌を有する症例に SAEを施行した。

2) $\mathrm{SAE}$ 後, 白血球数之血小板数の著明な増加がみ られ，化学療法が可能となり，転移性肺癌の消失をみ た.
3）SAEは脾機能え進症に対して有効であり，大い に活用しらるすのと考える。

本庭例報告の要旨は，第184回日本消化器病学会関東甲倨 越地方会（東京）で報告した。

$$
\text { 文㳯 }
$$

1) Maddison, F.E.: Embolic therapy of hypersplenism. Invest. Radiol., 8: 280-281. 1973.

2) Spigos, D.G. and Jonasson, O.: Partial splenic embolization in the treatment of hypersplenism. Am. J. Roentgenol., 132 : 777, 1979.

3）水野敏彦, 高橋雅明, 富永幹洋他：Patial Splenic Embolization（PSE）の適応と効果について。外 科, $45: 277-283,1983$.

4）平井賢治, 川副良治, 能谷雅信他：脾機能穴進症に 扰りる Transcatheter Splenic Arterial Embolization (TSAE) 療法一肝硬変, 肝細胞癌治療下 おける補助療法としての意義一, 日消誌，81： $2960-2966,1984$

5）高田忠敬, 安田秀喜, 内山勝弘他：脾喠, 血小板减 少症に対するSplenic Embolization の臨床的評 洒，日臨外会誌，45：1171-1176， 1984.

6）田尻 孝,梅原松臣, 矨淳他：外科頋域に拈け る肝硬変症の病態に対子る塞栓療法の意美，第85 回日本外科学会総会発表， 1985 .

7) 中村一夫，小野二六一，香月武人他：脾動脈塞栓政 により脾腫湯をきたした 1 症例一その危険性と反 省一，日消誌，82：315-318，1985。

8) Witte, C.L., Ovitt, T.W., Van Wyck, D.B., et al. : Lschemic therapy in thrombocytopenia from hypertention. Arch. Surg., 111: 1115-1121, 1976.

9) Castaneda-Zunica, W.R., Hammerschmidt, D.E., Sanchez, R., et al.: nonsurgical splenectomy. Am. J. Roentgenol., 129 : 805-811, 1977.

10) Owman, T., Luderquist, A., Alwmark, A., et al. : Embolization of the spleen for treatment of splenomegaly and hypersplenism in patients with portal hypertension. I Invest. Radiol., 14 : 457-464, 1979.

11) Wholey, M.H., Chamorro, H.A., Rao, G., et al.: Splenic infarction and spontaneous rupture of the spleen after therapeutic embolization. Cardiovasc. Radiol., 1 : 249-253, 1978.

12）山下精彦, 梅原松臣, 矨凛他：食道静脈瘤破裂 に対する塞栓療法, 救急医学, $9: 677--685$, へる す出版, 東京, 1985. 


\title{
CLINICAL POSSIBILITIES OF SPLENIC ARTERY EMBOLIZATION (SAE) BEFORE CHEMOTHERAPY FOR METASTATIC LUNG CANCER WITH HYPERSPLENISM
}

\author{
Matsuomi UMEHARA, Mikio ADACHI, Jun TEI, D.Y. KIM, Nobuhiro AOKI, \\ Yosuke TANAKA, Takashi TAJIRI, Kiyohiko YAMASHITA and Masahiko ONDA \\ 1st Department of Surgery, Nippon Medical School \\ (Director: Prof. Masahiko ONDA) \\ Seiichi HOSOI, Kazuyoshi HONDA and Tatsuo KUMASAKI \\ Department of Radiology, Nippon Medical School \\ Yasunori TERASHIMA \\ Department of Urology, Nippon Medical School
}

The patient was a 43-year-old man who received high orchiectomy for a malignant testicular tumor. One months after the operation, bilateral metastatic lung cancer was observed and chemotherapy was considered as the best choice for postoperative therapy. However, the method was thought unsuitable because of a severe leucopenia (WBC $2,000 / \mathrm{mm}^{3}$ ) and thrombocytopenia (platelet $6.4 \times 10^{4} / \mathrm{mm}^{3}$ ) due to hypersplenism affected by Schistosomiasis japonica. Splenic artery embolization (SAE) was thus proposed and carried out and led to improvement of the leucopenia and thrombocytopenia. After SAE, WBC and platelet count increased satisfactorily to $5,000 / \mathrm{mm}^{3}$ and $20 \times 10^{4} / \mathrm{mm}^{3}$, and chemotherapy was performed safely. In the course of the medication, temporary leucopenia occurred just after administration of the drug, but rapid recover of the cell count was regained after the discontinuity. Platelet count was maintained within the normal range during the medication. Four months after medication, metastatic lung cancer was not visualized in chest $\mathrm{X}$-ray. It is not uncommon that malignant tumor is combined with hypersplenism. In these cases, we suggest that SAE should be used for non-surgical treatment of hypersplenism. 